\title{
The Hero Versus the Initiate: The Western Ego Faced with Climate Chaos
}

\author{
Rachael A. Vaughan, M.A., M.F.T. \\ Each generation needs to discover the archetype of initiation for itself. \\ Joseph Henderson
}

The nightworld is where we are.

I say it. I say it till we may hear it.

And in that darkness, we remember what we love the most.

That itself is the candle.

Martin Shaw

We live in capitalism. Its power seems inescapable. So did the divine right of kings.

Ursula Le Guin

\begin{abstract}
The chaos caused by the global climate crisis is in the news in many forms and has also entered the consulting room: clients are increasingly naming their fear, despair, rage, and experience of impotence in the face of the unknown. This paper builds on the work of G. Albrecht and J. Bernstein, to investigate how we can face our feelings about climate crisis and live through this time without resorting to unhelpful defenses that block our ability to be present, engaged and effective. It examines the unconscious beliefs, habitual patterns, and defenses of the Western ego, which it presents as the mindset of Economism and the Capitalocene, and investigates its identification with the hero archetype. It pays homage to indigenous analyses of the issue in the work of J. Forbes and I Merculieff, and draws on the work of eco-ethical thinkers such as K. D. Moore, J. Butler, and A. L. Tsing, to suggest that the archetype of the initiate may be a better guide as we move into the uncertain, contingent future.
\end{abstract}

Keywords: Anthropocene, archetype, Capitalocene, climate change, cultural complex, ecopsychology, hero complex, Jungian psychology, psychological defenses, sostalgia, Western ego

The global climate crisis represents the ultimate in chaos: we do not know how far it will go, or how quickly it will unfold, and everything we do know seems to be accelerating (Wallace-Wells, 2019). It is in the news in many forms: fire, flood, extinction, refugees, rebellion. It has also entered the consulting room: clients are increasingly naming their fear, 
their despair, their rage, and their feelings of impotence in the face of the unknown. As I was writing the first draft of this paper, the temperature was spiking to an unprecedented 48 degrees Celsius (112 Fahrenheit) in Paris, and the Arctic was on fire. As I am editing the final draft, Australia is on fire. My Northern California kitchen pantry is stocked with boxes of N95 smoke masks and fire evacuation bags because of the devastating wildfires of the past two years. Trying to prepare for chaos is the new normal, as is feeling woefully unprepared in the face of it.

This paper investigates how we can live through our time without resorting to unhelpful psychological defenses that block our ability to be present, engaged and effective. It uses Jungian psychology to examine the limiting beliefs and thought patterns prevalent in the developed Western world, with its emphasis on action and progress, and suggests that a more humble way of being may be a better guide as we move into an uncertain, contingent future.

\section{Nature or Nurture: Anthropocene or Capitalocene?}

Our time is characterized by human-caused climate change and has accordingly been named the "Anthropocene." ${ }^{1}$ The term has caught on in popular culture, but has also been criticized from many sides because it enshrines a view of established, uncontested human domination that sees the natural world as merely a resource to be managed for human consumption (Christ, 2016). The various authors of the book Anthropocene or Capitalocene (J. Moore, 2016) have pointed out that the term “Anthropocene” erroneously frames the state of the planet today as the unavoidable consequence of our humanity, when on the contrary, it is the result of a specific set of political, social and economic choices, which not all humans have made.

J. Moore argued that the climate emergency has been caused, not by human nature, but specifically by capitalism. He proposed we name our time the "Capitalocene", since our era is "shaped by relations privileging the endless accumulation of capital." (J. Moore, 2016, p. 94) This point is important, and worth emphasizing, since if the chaos we have unleashed is the result of choice, then we have some agency over it: if we want to, we can make different, and hopefully better choices. These will not be easy, or simple, but the possibility is there.

Moore situated the origins of the Capitalocene in the rise of capitalism, but he meant capitalism in a wider sense than Marx. He situated its beginning well before the industrial revolution, in a fundamental change of mind-set in the West of Europe in the 16th century when there was, he said, a shift in focus from land productivity to labor productivity. In other words, at that time we stopped framing our relationship to the earth as one in which the land (in its beneficence) produces and we (gratefully, attentively) tend the land, and began framing it as one in which human labor produces while the land is merely a raw material for that production. Along with this shift went the gradual proletarianization of peasants, the enclosure of the commons, the extermination of the witches and the cunning

\footnotetext{
${ }^{1}$ The name was coined in the year 2000, by the Nobel-prize-winning atmospheric chemist Paul Crutzen, in order to capture the enormity of human impact on our planet’s life systems. "Anthro” is Greek for "man”, as in "human”. Thus the term literally means "the human epoch". The suffix "ocene” mirrors the naming of previous geological epochs - the three previous geological epochs having been named the Pliocene, Pleistocene, and Holocene.
} 
folk (Federici, 2004; Wilby, 2005), and the idea of "cheap nature” viewed as free raw material/resource (J. Moore 2016, pp. 78-115).

If we accept Moore's view of history, we in the West have been living within an instrumentalist mind-set that has gradually been gathering steam since the 16th century. It is only in the last 30 years or so that we are beginning to realize that the price of that mindset is too great. We need to look at the enormous cost of what we have achieved - a cost paid disproportionately by those not in the West, as R. Nixon (2011) pointed out in Slow Violence and the Environmentalism of the Poor. For as J. Moore (2016) explained, most humans are excluded from our definition of humanity in the Anthropocene/Capitalocene, which inflicts violence both fast and slow on indigenous and land-based people, thirdworld people, black and brown people, the working class and the poor, and upon the biosphere itself. Those of us who are (at least for now) considered human in the Anthropocene/Capitalocene are predominantly white, moneyed, and living in the developed world - the non-local "center” of global capitalism. (Moore, 2016)

I say "we" and "us" since I am situated in the developed West, and since I am appealing to those who are also situated there, either physically or economically. We are at the same time the greatest collective contributors to climate change, and the people with the most power to do something about it. By 'economically situated', I am referring to the fact that though these habits of thought, behavior and lifestyle originated in the West, they are now increasingly found worldwide. The ways of the West have spread globally like a pandemic virus $^{2}$ with the expansion of the American empire (Panitch \& Gindin, 2012), and now its mind-set can be found in the wealthy, higher-educated, industrialized class throughout the developed world. Nevertheless, the driving force behind globalization is still the corporatized United States, so I am going to refer to "the Western ego" for the psychic structure of selfhood formed under capitalism—one that has become so normalized that we do not even realize we are in it.

\section{The Western Ego and the Capitalist Mind-set}

In his book Living in the borderland, Jungian analyst J. Bernstein (2005) investigated the origins and limits of the Western ego and its role in creating the climate crisis. He stated:

Psyche, and consequently ego, are inherently constructs of culture; hence the western psyche is the totality of those elements that throughout history have created a "western" psychic consciousness and unconsciousness. The western ego is the conscious personalization of European/American cultural constructs and the personal and collective experiences that are the motivations of behavior. At the same time, the Western ego is influenced by unconscious elements. (p. 15)

In defining a specifically Western ego structure, Bernstein built on Jung's hypothesis of a cultural layer to the psyche, between the personal and archetypal level of being. This idea was further developed by J. Henderson (1984) and later by T. Singer and S. L. Kimbles (2004).

\footnotetext{
${ }^{2}$ Native American philosopher J. Forbes (1979) suggests that it is an actual virus: the wetiko virus, which carries "the disease of aggression against other living things, and more precisely, the disease of consuming of other creatures' lives and possessions” (p. xvi).
} 
Bernstein made no explicit link with political or economic systems, but his description of the Western ego supports the idea that it has been profoundly colonized by the values of capitalism. He noted that the Western ego is split from nature, and he characterized it as "intensely focused, highly mental, abstract, categorical, mathematical, mechanical, and wedded to linear time" (pp. 33-35). ${ }^{3}$ This analysis accords with the work of anthropologists E. C. Stewart and M. J. Bennett (2011) who identified an unquestioned belief in progress, action, effort, development, achievement, and forward movement as key to the American (aka Western) mind-set. These are all adaptive values for being a productive member of an advanced capitalist society, but they are no longer appropriate under our current circumstances.

Linking the Western ego and capitalism even more thoroughly, J. Cobb (1998) argued that the hegemonic religion in the US, Europe, and the entire developed world in our time is "Economism": "the belief that primary devotion should be directed to the expansion of the economy" (p. 28). Cobb emphasized that this system values people only by their contribution to markets, creates underclasses of excluded people, exploits the people of third-world countries, destroys the commons, violently suppresses resistance, splits the bond between people and land, and makes gains at the cost of the environment (pp. 3336). He wrote:

Those who view the world through the lens of economic theory, whether capitalist or Marxist, regard the specific conditions of the natural world as unimportant... What is prized is the transformation of natural resources into artificial products. Wealth is measured in terms of these products alone. In short, nature disappears from view. As a result, policies based on economic theory are insensitive to their effects on the natural world...For the first time in human history the living system on the surface of the planet appears seriously threatened by human activity. Yet this fact is ignored or denied by the dominant faith. (p. 36)

We are suffering now, not only because of the material results of our system's commodification of the natural world and our social relations, but also because "our conceptualization of the world itself allows commodification to stand as the sole way of relating to it” (Weber, 2019, p. 69). As T. Berry (2003) said, we need a new story. So let us turn now to the mythic, to understand the archetypal aspects of this paradigm.

\section{Identification with the Hero Archetype: Aggressive Action}

In the West and particularly in America, we prize effort, action, progress, decisiveness and achievement, and we look to individuals embodying these principles to lead us. Integral philosopher S. Kelly (2010) described the West as dominated by a heroic masculine principle with qualities of "competitive striving, independence or separativeness, dominance, and...a certain inflection of consciousness and rationality that stresses certainty, closure and rigidly hierarchical thinking” (Kelly, 2010, p. xiii). ${ }^{4}$ In Jungian

\footnotetext{
3 The origins and extent of this have been extensively described, for example by Bauman (2014), El Saffar (1994), Merchant (1980), J. Moore (2016), White (1967).

${ }^{4}$ Kelly associates these qualities with the solar masculine, but avoids essentialism by pointing out that they are not necessarily characteristic of masculinity as such, but rather the version of it found under patriarchy.
} 
terms, the Western ego has become identified with the hero archetype. Identification is a particular danger in Jungian psychology: archetypal energies can be inspiring and meaningful, so long as they are engaged with dialogically, such that we can consciously integrate them. Identifying with the archetype, however, leads to being taken over by it, which results in compulsive behavior and a lack of perspective.

B. Spector (2010), in his book Madness at the gates of the city: The myth of American innocence, presented a particularly North American hero mythology, in which the hero is remarkable for his violence, as well as for his unrelatedness. Like the Clint Eastwood character in a movie, the hero arrives, acts, and leaves. There is an emphasis on fighting and destroying: the hero pits himself against an enemy and wins the day by killing that enemy-counter-posed with an innocent victim who needs to be saved. ${ }^{5}$ The solution to trouble is simple: cast someone as innocent, and someone as the aggressor, kill the aggressor.

We see such heroic narratives in our widespread tendency to externalize climate change as an enemy to be fought, something impinging on us from outside. These narratives cast us as innocent victims to whom climate change is happening. According to this narrative, someone else must be at fault, and they must be made to stop. For example, there are various efforts underway to sue the heads of big oil companies for causing emissions, as though identifying and blaming a single perpetrator and punishing them could stop the impact of our use of energy. This will not work while our entire way of life is based on rampant consumption of fossil fuel, as I. Angus (2016) details in Facing the anthropocene: Fossil capitalism and the crisis of the earth system. But this crisis is not one that can be saved by heroically killing a monster. That archetype will not help us now. We are the monster.

Identified as Western culture is with the hero, Westerners tend to center themselves in their own lives. American ideology tells us that we can have it all, that we deserve it, that the sky is the limit. Thinking otherwise is judged as pathological, framed as an internal lack of abundance, or seen as evidence of self-sabotage. We do not like to hear that we may have to live smaller, more local lives, shop less, do without.

For Bernstein (2005), our only hope is "a continuing dynamic outside the ego", offered through reconnection with nature (p. 63). Bernstein suggested that the crisis we are in is an evolutionary stage: "a point in the history of humankind where the Western ego... and the Self are struggling/learning to function as coevolutionary partners” (p. 61). In saying this, he was applying C. G. Jung's (1971) model of the life cycle to our entire culture. According to that model, the first part of life is dedicated to success in the domain of the ego (establishing our place in the world, founding a career, becoming somebody), while the second half, usually initiated by a crisis, requires a shift to connection with the Self-the archetype of psychic wholeness that propels us to evolve on a personal level. Ironically, the Self is often symbolized by a mana figure such as the hero (Jung, 1971, pp. 460-461). And indeed, the hero archetype is important for the first half of life.

He also distinguishes solar from lunar masculinity: "the relational, sensitive, sensuous, intuitive man”. (Kelly, 2010, p. xv).

${ }^{5}$ Usually in this narrative, the innocents are white, and the aggressors either foreign, or of color (Spector, 2010). 
However, Jung (1963) warned that to continue indefinitely in heroic adventures is a mistake; in the second half of life we must turn toward the Self, in the search for soul and wholeness he called individuation. Psychological maturity means giving up the hero (Beebe, 1989, pp. xv-xvi). The archetype of the second part of life is that of the initiate, who must relinquish control and submit to the uncertainty of true change (Henderson, 2005). This is as true for a society as it is for an individual, and as a civilization we are at this juncture. But we do not want to submit. A recent study found that men in the US and China resist sustainable behavior because they find it "unmanly" (Brough \& Wilkie, 2016). As long as we frame masculinity, achievement and power within the heroic model, this attitude will surely continue.

Bernstein (2005) referred to the psychic inertia of the Western ego, which "resists, powerfully, anything that aims at changing its self-definition and outward orientation" (p. 34). But Henderson (2005) noted that eventually the hero overreaches himself in his endless quest for power. When this happens, “a will-to-power normally gives way to a willingness to submit, forced inevitably upon the developing ego by inner laws of change, or by outer necessity to conform to reality (Freud's 'reality principle')...this submission takes place only against the full force of a resistance to change inherent in the hero-image" (p. 30; my emphasis.) This is the point of initiation. It is also exactly where we are, collectively. In the "Dark Mountain Manifesto,” P. Kingsnorth and D. Hine (2009) wrote:

We find ourselves, all of us together, poised trembling on the edge of a change so massive that we have no way of gauging it. None of us knows where to look, but all of us know not to look down. Secretly, we all think we are doomed: even the politicians think this; even the environmentalists. Some of us deal with it by going shopping. Some deal with it by hoping it is true. Some give up in despair. Some work frantically to try and fend off the coming storm. Our question is: what would happen if we looked down? Would it be as bad as we imagine? What might we see? Could it even be good for us? We believe it is time to look down.

\section{Living the Chaos of Paradigm Shift: Psychic Defenses against Facing Climate Change}

Shifts between paradigms are often characterized by crisis (Kuhn, 1962). Our experience of such a crisis is often one of (incipient) chaos. We can feel the end of the old, but we cannot yet see what will emerge to take its place. In a crisis, we feel an urgent need to do something, though at the same time, it is hard to perceive accurately what is happening, or work out what needs to be done. In such states of urgency, the pre-frontal cortex can be over ruled by the alarm sirens of the amygdala, making it even harder to think straight. Often, our solution is to dissociate, temporarily cutting off emotional reactions and body sensations in order to fight or flee. But if the threat is great, and we see no way out through fight or flight, then we freeze (Ogden et al., 2006).

Our culture is experiencing the entire gamut of these reactions to threat. While geoengineering solutions are being proposed, and important-sounding summits are being held (and leading to no action at all), the general population is increasingly affected by 
"sostalgia,"6 eco-anxiety, and fear of extinction (Albrecht et al., 2007; Marks, 2019). In order to make the changes we need to make, we must face the reality of where we are, but the truth of the climate crisis is so dire that it is often just too hard to bear the emotions that arise in response to it, which causes us to mobilize psychic defenses against unbearable anxiety. Here are some of the common ones employed to cope with climate change:

- Most obviously: denial. Even though more than $97 \%$ of scientists agree that global warming is real and largely human-caused, ${ }^{7}$ climate change deniers cling to the outlying possibility that all the data is wrong. It is easy to poke fun at climate change deniers, but in fact all of us, as a population, are indulging in denial to some extent by continuing with business as usual, while the clock ticks away ${ }^{8}$.

- The defense of omnipotent control reveals itself in various forms of something E. Morozov (2014) termed "solutionism." The term describes the recasting of complex situations as problems that can be easily solved with technological solutions: an approach likely to result in unexpected consequences that could cause more damage than the problems they seek to address (pp. 5-6). I am using it to refer to various geo-engineering projects such as proposals to release particles into the stratosphere to reflect sunlight and cool the atmosphere. This project is presented as "cheaper" than reducing fossil fuel use, and testing is going ahead ${ }^{9}$ despite the fact that it may render our skies permanently grey, or at worst, trigger a "nuclear winter." Who calculated the price of a blue sky, or stars shining at night? Who set the value of money above a clear view of the moon? We have to ask these questions. They are vital. Another example is "direct air capture”, which involves building factories to scrub carbon from the atmosphere-something that sounds useful until one reflects that this is exactly what forests do. The fact that we are clear-cutting forests, while proposing to cause even more emissions to build factories to do the work they do, is iconic. ${ }^{10}$

- The defense of splitting and projection is seen in the temptation to scapegoat other people for the climate crisis, while resisting the necessity to reduce one's own resource consumption, or activating for real change at the level of infrastructure. One example is the effort to sue the top executives of oil companies for monetary compensation for climate change (Hasemyer, 2020). This will not work, because "global warming isn't a perpetrator; it's a conspiracy” (Wallace-Wells, 2019, p. 20). We are all responsible.

- The defense of withdrawal is seen in various forms of survivalism, projects to build border walls, NIMBYism, and all other responses that involve trying to ensure

\footnotetext{
6 "Sostalgia” is a term coined by G. Albrecht (2019) to describe distress at the forced loss of beloved places.

${ }^{7}$ Sourced at https://www.ucsusa.org/global-warming/science-and-impacts/science/scientists-agree-globalwarming-happening-humans-primary-cause.

${ }^{8}$ Retrieved from https:/www.forbes.com/sites/mikehughes1/2019/08/02/climate-change-18-months-tosave-the-world/\#6131957f49bd.

${ }^{9}$ Sourced at https://www.forbes.com/sites/trevornace/2018/12/05/harvard-scientists-begin-experiment-toblock-out-the-sun/\#251d3c0740c2.

${ }^{10}$ Equally iconic is the fact that in this instrumentalist equation, the other functions provided by forests are disregarded: the provision of home, habitat, and livelihood for indigenous humans, birds, insects, and other creatures, the diversity of plants, the protection of watersheds, the sheer beauty of the forest, and so on.
} 
one's own survival in the chaos of a global breakdown of civilization (Osnos, 2017). Often withdrawal is closely interwoven with the defense of undoing, in the form of naïve fantasies of returning to a more natural life, living on the land, and so on, after the end of civilization.

- And finally, I see the manic defense in the Trump administration's rollbacks of restrictions on pollution and emissions, as well as legislation to protect the environment. We also see it in our spiraling consumption. Global emissions reached an all-time high in 2018 and are still climbing (Harvey, 2018).

It is very, very hard not to defend against the facts. The implications for our lives and for the scale of the changes we need to make are so massive. The task, and the responsibility, are so overwhelming. As M. Shaw (2019) said, "Staggering spiritual repair is called for. It is not just those bad white men in power that did this. We all did." Thus we all need to face what we have jointly created.

\section{A New Paradigm: Radical Humility}

In order to face where we are without fragmenting, we need at least some hope. Not what I would call "big H hope"-the hope for success, victory, and a prize, that goes with the hero archetype-but "small h hope"; the hope the initiate needs, in the form of a flickering candle to hold as she heads down into the darkness, not knowing what may lurk ahead of her. V. Havel (1990) wrote about this kind of hope as "an orientation of the spirt, an orientation of the heart." He said that it is

not the same as joy that things are going well, or willingness to invest in enterprises that are obviously headed for early success, but rather an ability to work for something because it is good, not just because it stands a chance to succeed. The more unpromising the situation in which we demonstrate hope, the deeper that hope is. Hope is not the same thing as optimism. It is not the conviction that something will turn out well, but the certainty that something makes sense, regardless of how it turns out...It is also this hope, above all, that gives us the strength to live and continually to try new things, even in conditions that seem as hopeless as ours do, here and now. (pp. 181182)

One of the most paradoxically hopeful texts, in this sense of "small h hope", that I have come across in recent years is A. L. Tsing's (2015) book The Mushroom at the end of the world: On the possibility of life in capitalist ruins. In this book, Tsing pointed out that capitalism represents itself as the only viable option. It presents us with a false choice: on the one hand progress, expansion, and continual advance toward some better future that is worth the sacrifice of our lives (and our world) now, or on the other failure, ruin and collapse. Capitalism tells us if we stop moving forward, we will die, like a shark.

Tsing urged us to step out of capitalism's totalizing narrative and attend to what is happening outside of it. She did not promise us a happy ending, but her research suggests the possibility of continued life in the ruins of the comfortable stability we consider so indispensable now. She indicated that solutions to survival will necessitate finding or establishing refugia for resurgence and regrowth, ${ }^{11}$ while adapting to what is possible and

\footnotetext{
11 This potential for restoration is something that may also be approaching a tipping point (Tsing, 2017).
} 
available under the circumstances. Such solutions are small, local, contingent, shifting, ephemeral, non-scalable, and based on networks and relationships of community. Such is not the terrain of the hero.

Nothing about Tsing's vision is grand, lasting, comfortable, or stable, but it offers a small hope of survival, resurgence, and a decent, if humble, life based on human ingenuity and resourcefulness, ecosystem resilience, humility, and sharing. How do we foster these qualities in place of those of the hero? Perhaps we only do it when we have no other choice. Henderson (2005) wrote that failure is an important aspect of initiation into maturity. He also wrote that this initiation is iterative; happening in stages, with no fanfare, no extrinsic reward, and no end:

This final stage of initiation...is represented by no rite of entrance or exit; it is not a state of containment or incubation, nor is it a state of release or liberation. It is a unique state of being in the world which cannot be symbolized except very tentatively. (p. 205)

Our initiation as a collective requires us to acknowledge that we have already destroyed the very conditions under which we and everything else alive today evolved (WallaceWells, 2019), and to avow the enormity of our error. It demands that we bow to our own mortality and acknowledge our total dependence on the rest of the biosphere, as well as the fact that there is a higher goal in life than our own gratification: that of the continuance of life. Such an initiation commands us to step forward honestly, with our hearts in our open willing hands, into the greatest uncertainty of our lives.

\section{Leadership: The Way of the Initiate}

We need leadership in response to climate chaos, but we need it from a humble ego in conscious dialogue with the Self, the world, and the world's others in all their forms, rather than from a heroic ego, obsessed with its own survival at all costs. Leadership by the initiate is related, humble, listening, and inclusive. This kind of leader comes with open questions rather than agenda-driven answers. The initiate is neither passive nor weak. Its humble approach to problem-solving values real understanding over reaction. S. Cain (2013) suggested its relative introversion is likely to provide better solutions than the reactive extravagance of the hero.

A recent example of this kind of leadership is that of the Prime Minister of New Zealand, Jacinda Ardern. After the mass shootings at the mosques in Christchurch, she provided a model for compassion, joining with her country's Muslim population, wearing hijab to attend memorial services and respectfully quoting from the Koran. She did not shy away from naming the Islamophobia and racism behind the shootings, and she modelled anti-racism: opening parliament with the Arabic greeting "As Salaam Alaikum," and responding to Donald Trump's offer of support by requesting "Sympathy and love for all Muslim communities.” At the same time, she acted swiftly to change New Zealand's gun laws and ban assault rifles and military-style semi-automatics (Lester, 2019).

The initiate integrates mind with heart and soul, ${ }^{12}$ and this integration is key. Aleut elder I. Merculieff (2017) recently delivered a message from the indigenous elders of the

\footnotetext{
${ }^{12}$ It is, of course, noteworthy that Jacinda Ardern is a woman, and one could conclude that her distinctive leadership style results from her gender. But I think there are more complex dynamics at play than gender
} 
world, whose opinion is that our civilization cannot solve its predicament from our current position of disconnected, mechanistic, (pseudo-)objective rationality. Instead, the elders say, we must shift to the heart-and do it now-or die. The elders' message is as urgent as that of H. J. Schellnhuber, founder and now director emeritus of the Potsdam Climate Institute, who said in 2019 that we could not afford to wait until even 2020 to address climate change (McGrath, 2019). And yet we are now in 2020, with no progress made.

\section{The Path of the Initiate: Love and Grief}

Shifting to the heart now requires that we address our feelings about climate change. When we connect to those feelings, what we often experience is overwhelming grief (Albrecht et al., 2007; Macy and Brown, 1998). Focusing our attention on recognizing, expressing and validating climate change grief can seem solipsistic and self-indulgent, but grief felt and communicated can catalyze change (Kretz, 2017). It is politically useful.

Feeling grief can pierce denial-ours and that of others-and unfreeze despair. Grieving is a traditionally a communal task (Weller, 2011), and sharing it with understanding others can restore our access to the social engagement system, bringing us out of a traumatized, terrified freeze response (Ogden et al., 2006). When we emerge from a freeze state, we are better able to access the appropriate fight response we need to work collectively for change.

Grief is an act of resistance: it refuses to forget (Cunsulo \& Landman, 2017, p. 14). Expressed collectively it can force public recognition of peoples, creatures, land, or water not represented as "grievable" (Butler, 2010). This is what happened in New Zealand, where Jacinda Ardern's public grief in solidarity with the Muslim community emphasized the full citizenship and humanity of the victims of Islamophobia, stopping any further racism in its tracks. By modelling the acceptability of grief as well as appropriate anger, she mobilized collective support for the actions that led to stricter gun laws.

Grief is mobilizing because it opens a space in which we can feel our love-for the world, for each other, and for our children, whose chance at a livable life depends on how much we curb warming now. We need to ask how it became unacceptable to talk about love. Who disparaged such discourse as hopelessly romantic and disconnected from reality? We have to stand against the utilitarian values of capitalism and give ourselves permission to speak about love, or inhabit a world increasingly devoid of it.

The ethicist K. D. Moore (2016) has declared her intention to stop trying to craft utilitarian, economistic arguments for saving nature, because she is sick of arguing within the dominant paradigm of destruction. Instead, she reclaimed the right to say she wants us to save nature because she loves the frogs, and the trees, and the water, and the birds. Embodying the archetype of the initiate allows us to drop our stance of exceptionalism, and embrace our place in the "commons of reality" (Weber, 2019), as simply one member of one species in the profoundly interrelated, entangled web of life-what Merleau Ponty called "the flesh of life" (Abrams, 1996).

essentialism can account for, and as a Brit raised under Margaret Thatcher, I can testify that female gender does not make a better leader. Cultural feminists argue that "bad" women leaders have been denatured by patriarchy, but since the patriarchy is identified with the hero and the solar masculine (Kelly, 2010), this brings us back to where we started. 
I am not suggesting that all we need do is feel. Feeling must be a prelude to action, and surviving the Anthropocene requires radical social change to replace fossil capitalism with an ecological civilization (Angus, 2016). A shift to the heart supports that. It encourages us to shift from (merely) protesting what we want not to happen, to creating what we do want now. K. D. Moore (2016) referred to this as moving from a morality of prohibition to a morality of affirmation (p. 17). D. Graeber's (2004) work on counter-powers is useful here, especially in the light of D. Orlov's (2011) writings on surviving the fall of the Soviet Union. And D. Fleming's (2016) pragmatic vision of a new type of local, small-scale, relational economy based on benevolence rather than competition is instructive. Fleming wrote:

The question to consider...is not whether the crash will happen, but how to develop the skills, the will and the resources necessary to recapture the initiative and build the resilient sequel to our present society. It will be the decentralized, low-impact human ecology which has always taken the human story forward from the closing down of civilizations: small-scale community, closed-loop systems, and a strong culture. (p. 8)

\section{Conclusion}

It is hard to talk about-and think about_climate change: partly because it is what $\mathrm{T}$. Morton (2013) called a "hyper-object"-a system so large and complex that we cannot truly comprehend it. (Wallace-Wells, 2019) And it is partly difficult because, as WallaceWells pointed out:

The only factually appropriate language is of a kind we've been trained, by a buoyant culture of sunny-side-up optimism, to dismiss, categorically, as hyperbole. Here, the facts are hysterical, and the dimension of the drama that will play out ... incomprehensibly large... There is simply no analogy to draw on, outside of mythology and theology_and perhaps the Cold War prospect of mutually assured destruction. (p. 29)

In this paper, I have tried, despite Wallace-Wells' well-observed pitfalls, to reflect on the enormity of climate change, drawing on Jungian archetypal psychology to represent our task at this time as one of collective individuation. I have suggested that we must shift from identification with the hero to a more soulful, embodied, and uncertain engagement with the archetype of the initiate. This means that we must feel, grieve, accept, and respond to reality in ways that involve clear sight and humility, sacrificing our illusions of control and victory to the reality that we are at "an inflection point of consequence that changes the name of the 'game' of life on earth for everybody and everything” (Harraway, 2015, p. 159). Only then do we stand any chance at all of being able to salvage our own lives, those of our children, and those of the other creatures of the Holocene.

\section{Contributor}

Rachael Vaughan M.F.T. holds an M.A. in Depth Psychology from Pacifica Graduate Institute, California, as well as an M.A. in Linguistics from the University of Edinburgh, Scotland. She is an Associate Professor in the Integral Counselling Psychology Department at the California Institute of Integral Studies in San Francisco, and runs a bilingual therapy 
practice. She holds a Permaculture Design Certificate and has an active interest in ecopsychology, grounded in gardening, nature art, and rural life.

\section{References}

Albrecht, G. A. (2019). Earth Emotions: New Words for a New World. Ithaca, NY: Cornell University Press.

Albrecht, G., Sartore, G., Connor, L., Higginbotham, N., Freeman, S., Kelly, B., ... \& Pollard, Georgia. (2007). Solastalgia: The Distress Caused by Environmental Change. Australasian psychiatry: bulletin of the Royal Australian and New Zealand College of Psychiatrists. 15 (1), 95-98.

Abrams, D. (1996). The Spell of the Sensuous. New York, NY: Vintage Books.

Angus, I. (2016). Facing the Anthropocene: Fossil Capitalism and the Crisis of the Earth System. New York, NY: Monthly Review Press.

Bauman, W. (2014). Religion and Ecology: Developing a Planetary Ethic. New York, NY: Colombia University Press.

Beebe, J. (1989). Introduction. In Jung, C. G. Aspects of the Masculine (pp vii-xvii). New York, NY: Routledge.

Bernstein, J. (2005). Living in the Borderland. New York, NY: Routledge.

Berry, T. (2003). The New Story: Comments on the Origin, Identification and Transmission of Values. In A. Fabel \& D. St John (eds) Teilhard in the $21^{\text {st }}$ Century: The Emerging Spirit of Earth (pp 77-88). Maryknoll, NY: Orbis Books.

Brough, A. R. \& Wilkie, J. E. B. (2016) Men Resist Green Behavior as Unmanly. Scientific American. Retrieved from https://www.scientificamerican.com/article/men-resist-green-behavior-asunmanly/

Butler, J. (2010). Frames of War: When is Life Grievable? New York, NY: Verso.

Cain, S. (2013). Quiet: The Power of Introverts in a World That Can't Stop Talking. New York, NY: Broadway Books.

Christ, E. (2016). On the Poverty of Our Nomeclature. In J. W. Moore (Ed) Anthropocene or Capitalocene: Nature, History, and the Crisis of Capitalism (pp 14-33). San Francisco, CA: Kairos books.

Cobb J. B. Jr. (1998). The Earthist Challenge to Economism: A Theological Critique of the World Bank. London, UK: Palgrave Macmillan.

Cunsulo, A. and Landman, K. (Eds). (2017) Mourning Nature: Hope at the Heart of Ecological Loss. London, UK: McGill-Queen's University Press.

El Saffar, R. A. (1994). Rapture Encaged-The Suppression of the Feminine in Western Culture. New York, NY: Routledge.

Federici, S. (2004) Caliban and the Witch: Women, the Body and Primitive Accumulation. Brooklyn, NY: Autonomedia.

Fleming, D. (2016). Surviving the Future: Culture, Carnival and Capital in the Aftermath of the Market Economy. White River Junction, VT: Chelsea Green.

Forbes, J. (1979) Columbus and Other Cannibals. New York, NY: Seven Stories Press. 
Graeber, D. (2004) Fragments of an Anarchist Anthropology. Cambridge, UK: Prickly Paradigm Press.

Harvey, C. (2018). CO2 Emissions Reached an All-Time High in 2018. Scientific American. Retrieved from https://www.scientificamerican.com/article/co2emissions-reached-an-all-time-high-in-2018/

Hasemyer, D. (2020). Fossil Fuels on Trial: Where the Major Climate Change Lawsuits Stand Today. Inside Climate News. Retrieved from https://insideclimatenews.org/news/04042018/climate-change-fossil-fuelcompany-lawsuits-timeline-exxon-children-california-cities-attorney-general

Havel, V. (1990) Disturbing the Peace: A Conversation with Karel Huizdala. New York, NY: Vintage.

Henderson, J. L. (1984). Cultural attitudes in psychological perspective. Toronto, Canada: Inner City Books.

Henderson, J. (2005) Thresholds of Initiation. Asheville, NC: Chiron Publications.

Johnson, T. (2018) Radical Joy for Hard Times: Finding Meaning and Making Beauty in Earth's Broken Places. Berkeley, CA: North Atlantic Books.

Jung, C. G. (1971). Psychological types (R. F. C. Hull, Trans.) (H. Read et al., Eds.), The collected works of C. G. Jung (Vol. 6). Princeton, NJ: Princeton University Press. (Original work published 1921).

Jung, C. G. (1963). Memories, Dreams, Reflections. New York, NY: Pantheon Books.

Kelly, S. (2010) Coming Home: The Birth and Transformation of the Planetary Era. Great Barrington, MA: Lindisfarne Books.

Kingsnorth, P. and Hine, D. (2009). Dark Mountain Manifesto. Retrieved from https://dark-mountain.net/about/manifesto/

Kretz, L. (2017). Emotional Solidarity: Ecological Emotional Outlaws Mourning Environmental Loss and Empowering Positive Change. In Cunsulo, A. and Landman, K. (Eds). Mourning Nature: Hope at the Heart of Ecological Loss (pp 258-291). London, UK: McGill-Queen’s University Press.

Kuhn, T. (1962). The Structure of Scientific Revolutions. Chicago, IL: University of Chicago Press.

Lester, A. (2019) The Roots of Jacinda Ardern's Extraordinary Leadership After Christchurch. New Yorker Magazine. Retrieved from https://www.newyorker.com/culture/culture-desk/what-jacinda-ardernsleadership-means-to-new-zealand-and-to-the-world

Macy, J. and Brown, M. Y. (1998). Coming Back to Life: Practices to Reconnect Our Lives, Our World. Gabriola Island, Canada: New Society Publishers.

Marks, A. (2019). How the Mental Health Community Is Bracing for the Impact of Climate Change. Rolling Stone Magazine. Retrieved from https:/www.rollingstone.com/culture/culture-features/how-climate-changeaffects-mental-health-835807/ 
McGrath, M. (2019) Climate Change: 12 Years to Save the Planet? Make that 18 Months. BBC News. Retrieved from https://www.bbc.com/news/scienceenvironment-48964736

Merchant, C. (1980). The Death of Nature: Women, Ecology, and the Scientific Revolution. New York, NY: HarperOne.

Merculieff, I. (2017). Panel discussion. Geography of Hope Conference: Ancestors and the Land, Our Past, Present and Future. March 17-19, 2017. Point Reyes, CA.

Moore, J. (2016). The Rise of Cheap Nature. In Moore, J. W. (Ed) Anthropocene or Capitalocene: Nature, History, and the Crisis of Capitalism (pp. 78-115). San Francisco, CA: Kairos books.

Moore, K. D. (2016). Great Tide Rising: Towards Clarity and Moral Courage in a Time of Planetary Change. Berkeley, CA: Counterpoint.

Morozov, E. (2014). To Save Everything, Click Here: The Folly of Technological Solutionism. New York, NY: PublicAffairs.

Morton, T. (2013). Hyperobjects: Philosophy and Ecology after the End of the World. Minneapolis, MN: University of Minnesota Press.

Nixon, R. (2011). Slow Violence and the Environmentalism of the Poor. Cambridge, MA: Harvard University Press.

Ogden, P., Minton, K., \& Pain, C. (2006). Trauma and the Body: A Sensorimotor Approach to Psychotherapy. New York, NY: W. W. Norton \& Company.

Orlov, D. (2011). Reinventing Collapse: The Soviet Example and American Prospects. Gabriola Island, Canada: New Society Publishers.

Osnos, E. (2017). Doomsday Prep for the Super-Rich. New Yorker Magazine. Retrieved from https://www.newyorker.com/magazine/2017/01/30/doomsday-prep-for-thesuper-rich

Panitch, L. and Gindin, S. (2012). The Making of Global Capitalism: The Political Economy of American Empire. New York, NY: Verso.

Shaw, M. (2019) We Are In The Underworld And We Haven't Figured It Out Yet. Retrieved from https://medium.com/@schoolofmyth/we-are-in-the-underworldand-we-havent-figured-it-out-yet-5d48d2c988aa

Singer, T., \& Kimbles, S. L. (2004). The cultural complex: contemporary Jungian perspectives on psyche and society. New York, NY: Routledge.

Spector, B. (2010). Madness at the gates of the city: The myth of American innocence. Oakland, CA: Regent Press.

Steward, E. C. and M. Bennett. (2011). American Cultural Patterns: A Cross-Cultural Perspective. Boston, MA: Nicholas Brealey Publishing.

Tsing, A. L. (2015). The Mushroom at the End of the World. Princeton, NJ: Princeton University Press.

Tsing, A. L. (2017). A Threat to Holocene Resurgence is a Threat to Livability. In Brightman M and J Lewis (Eds) The Anthropology of Sustainability (pp. 51-66). New York, NY: Palgrave. 
Wallace-Wells, D. (2019). The Uninhabitable Earth: Life After Warming. New York, NY: Tim Duggan Books.

Weber, A. (2019). Enlivenment: Toward a Poetics for the Anthropocene. Cambridge, MA, MIT Press.

Weller, F. (2011). Entering the Healing Ground: Grief, Ritual and the Soul of the World. Santa Rosa, CA: Wisdom Bridge Press.

White, L. Jr. (1967). The Historical Roots of our Ecological Crisis. Science, Vol 155, Isue 3767 pp. 1203-1207.

Wilby, E. (2005). Cunning Folk and Familiar Spirits: Shamanistic Visionary Traditions in Early Modern British Witchcraft and Magic. Brighton, UK: Sussex Academic Press. 